\title{
Syllable structure and vowel/zero alternations in Moroccan Arabic and Berber
}

\author{
Mohamed Lahrouchi \\ (CNRS \& University of Paris 8)
}

The Modern Arabic dialects of the Maghreb have three phonemic vowels /i, a, u/. These dialects are generally said to have lost the short vowels of Classical Arabic (henceforth, CA) and to have developed a short central vowel [ə], used to break up consonant clusters. ${ }^{1} \mathrm{~A}$ rapid comparison between CA and Moroccan Arabic (henceforth, MA) actually reveals that the latter lost length contrast in the vowels. In a number of items shared by these languages, there is a regular change whereby the long vowels of CA correspond to short vowels in MA, whereas short vowels in CA disappear in MA, resulting in consonant clusters often simplified by means of vowel epenthesis. The following examples illustrate the phenomenon:

$\begin{array}{lll}C A & M A & \\ \text { kataba } & \text { ktəb } & \text { 'he wrote' } \\ \text { kita:b } & \text { ktab } & \text { 'book' } \\ \text { qalb } & \text { qəlb } & \text { 'heart' } \\ \text { sa:hama } & \text { sahəm } & \text { 'he contributed' } \\ \text { kari:m } & \text { krim } & \text { 'generous' }\end{array}$

The same situation arises in the Berber languages ${ }^{2}$, except in Tashlhiyt, which allows complex consonant clusters without any vowels (see Dell \& Elmeldlaoui 2002, and Ridouane 2008). The correspondences in (2) are good examples in this respect:

(2)

$\begin{array}{lll}\text { a. } & C A & \text { Tamazight Berber (Taïfi 1991) } \\ \text { d'alama } & \text { d'ləm } & \text { 'accuse wrongly' } \\ \text { Palba:b } & \text { lbab } & \text { 'the door' } \\ \text { yarraba } & \text { yərrəb } & \text { 'go west' }\end{array}$

\footnotetext{
${ }^{1}$ Unlike other Maghrebi dialects, Tunisian and Lybian Arabic use [i] as an epenthetic vowel: For instance, CA $x u b z$ 'bread' and katabtu 'I wrote' are realized in Tunisian as xubiz and ktibit (see Wise 1983: 175). Similar examples are found in Lybian: CA $t^{\prime}$ iff 'child' and fazr 'dawn' are realized as t'sifil and fazir (see Elramli 2012 : 67).

${ }^{2}$ Berber refers to an Afroasiatic group of languages spoken in large parts of North Africa, mainly in Morocco and Algeria, and to a lesser extent in Mauritania, Mali, Niger, Libya, Egypt, Tunisia and Burkina Faso. Large Berber-speaking communities are also found in Western Europe and Canada. In Morocco, three main varieties are distinguished: Tamazight and Tashlhiyt, the varieties investigated here, are spoken in the Central and Southern Morocco, respectively; Tarifit is spoken in Northern Morocco. Kabyle is the main variety spoken in Algeria. Tamashek or Touareg is found in Niger, Mali and southern Algeria (see Chaker 1992).
} 
yirba:1 ayərbal 'sieve'

b. $\quad$ Tashlhiyt Berber

$\begin{array}{lll}\text { sa:fara } & \text { safr } & \text { 'travel' } \\ \text { la:haqa } & \text { laћg } & \text { 'reach, pursue' } \\ \text { alkita:b } & \text { lktab } & \text { 'the book' } \\ \text { Pibri:q } & \text { lbriq } & \text { 'tea-pot' }\end{array}$

The situation depicted in MA reflects the loss of the ability to associate peripheral vowels to non-branching nuclei, according to Lowenstamm (1991: 959). That is to say, CA short vowels do not surface in MA because they have access to only one skeletal position (see also Kaye 1990). ${ }^{3}$ They remain silent as long as the resulting consonant cluster does not violate the language's syllabic requirements. The general observation is that MA, like Berber, prohibits any sequence of more than two consonants. For example, the $3^{\text {rd }}$ masculine singular perfective $k t \partial b$ (1a) has only one epenthetic vowel, whereas the corresponding $2^{\text {nd }}$ singular imperfective taktab 'you write' resorts to a double epenthesis. More interestingly, the position of the vowels can vary depending on the nature of the suffix. The epenthetic vowel which appears between the last two consonants in $k t a b$ shifts leftward when a vowel-initial suffix is added (e.g. katb-u 'they wrote', katb-at 'she wrote').

Standard syllable-based analyses generally view the facts just introduced as evidence against complex constituents (see Benhallam 1990, 1989/90, Haddad 1984, Hall 2011, among others), while those couched within the framework of Government Phonology (Kaye, Lowenstamm \& Vergnaud 1990) make use of empty vocalic nuclei in order to derive the surface clusters. This chapter provides a general overview of these analyses and highlights their implications on the syllable structure of MA and Berber. Moreover, it argues following Guerssel (1990, 1992), Kabbaj (1990) and Kaye (1990) that (i) Tamazight Berber and MA have neither complex onsets nor complex codas, and that (ii) the vowel-zero alternations observed therein are better analyzed in terms of lateral relations between nuclei rather hierarchical syllable structure. In Tashlhiyt Berber, where epenthetic vowel is found, syllabic consonants arise. The distribution of these consonants will be shown to play a central role in determining the shape of the causative prefix in the same way plain vowels do in Tamazight Berber.

\footnotetext{
${ }^{3}$ The proposal has been extented to the Berber languages by Jebbour 1993, Idrissi 2000a, Bendjaballah 2001, Lahrouchi 2001, 2003, and Lahrouchi \& Ségéral 2010, among others.
} 


\section{Syllable-based approaches}

A large body of literature has been devoted to vowel-zero alternations. They have been studied in many unrelated languages such as French (Dell 1973, Charette 1990), Polish (Gussmann 1980), Dutch (Booij 1995, Oostendorp 1995), Tangale (Nikiema 1989), Arabic (Benhallam 1980, 1989/90, Haddad 1984, Itô 1989, Kaye 1990, Ali et al. 2008, and Hall 2013), and Berber (Bader 1985, Kossmann 1995, Coleman 1996, 2000, Bendjaballah 1999, 2001, Idrissi 2000a, 2000b, Lahrouchi 2001, 2003, Lahrouchi \& Ségéral 2010, and Ben Si Said 2014). In many cases, the alternating vowels are analyzed as instances of epenthesis, which allows resyllabifying phonotactically illicit consonant clusters. As a matter of fact, epenthesis occurs in different structural contexts, including the coda position (see Booij 1995 on Dutch, and Awbery 1984 on Welsh), the onset (see Itô 1989 on Temiar), and between identical consonants such as English meld[ə]d and $\operatorname{tax}[\mathrm{I}] s$ (see Frankiewicz 2001, and Bauer 2015).

\subsection{No complex coda}

In the Modern Arabic dialects, it is generally argued that vowel epenthesis occurs into $\mathrm{CC}$ clusters to avoid undesirable complex codas, as opposed to complex onsets which may occur in the Western (Maghrebi) dialects. Evidence for this statement is given in MA (Benhallam 1980, 1989/1990, Kaye 1990, and Boudlal 2001, 2006/2007) and Lebanese Arabic (Haddad 1984, and Hall 2013) below.

\begin{tabular}{llll} 
(3) & Moroccan Arabic & \multicolumn{2}{l}{ Lebanese Arabic } \\
a. & rkəb & rikib & 'ride' \\
& ktəf & kitif & 'shoulders' \\
& qfəl & Pifil & 'lock' \\
& fhəmna & fihimna & 'he understood us' \\
b. & kəbf & kibi $\sim$ kibJ & 'ram' \\
& səbt & sabit $\sim$ sabt & 'Saturday' \\
& qərd & Pirid $\sim$ Pird & 'monkey' \\
nəfs & nafis $\sim$ nafs 'self'
\end{tabular}

In (3a), both languages epenthesize a vowel between the last two consonants, which would otherwise form a complex coda. ${ }^{4}$ The forms in $(3 b)$ behave the other way around: the last two consonants remain unaffected in MA, while in Lebanese Arabic they can be subject to epenthesis, leading to forms of the same word in free variation. Based on these facts, one

\footnotetext{
${ }^{4}$ The quality of the epenthetic vowel in Lebanese Arabic differs from that in Moroccan Arabic, as can be seen from the data in (3). Generally speaking, the Leventine dialects use the high front [i], while the dialects of the Maghreb generally use [ə].
} 
can either argue that the coda may be complex in both languages or refer to some categoryspecific epenthesis to explain why the forms in (3b) behave differently (Echchadli 1986). Another alternative consists in analyzing the final consonant as extrasyllabic (Kaye et al. 1986), or adjoined to the coda by a post-lexical rule (Kenstowicz 1986). This ammounts to saying that the grammar of the modern dialects has no syllable with a complex coda, and that those of the type in (3b) are marginal syllables, restricted to very specific contexts. Indeed, as noticed by Kaye et al. (1986: 62), the CC clusters which would otherwise result in illicit complex codas occur only at end of the word. In word-internal position, they all behave as heterosyllabic.

The same reasoning holds for initial CC clusters (3a). MA tolerates such clusters word-initially, which the standard syllable theory would analyze as complex onsets. In the next section, we show that these clusters do not behave as branching onsets.

\subsection{No complex onsets}

One crucial piece of evidence against complex onsets in MA relates to sonority. Wordinitial clusters are much less restricted in MA than they are in languages with genuine branching onsets. While most Indo-European languages require that \#CC clusters always have a rising sonority profile (e.g. English blue, true; French plat 'dish', bras 'arms'), MA imposes no sonority restriction on their distribution. Consider the following examples $(\mathrm{O}=$ obstruent, $\mathrm{S}=$ sonorant $)$.

a. OS

$\begin{array}{ll}\text { Jra } & \text { 'he bought' } \\ \text { sni } & \text { 'sign' } \\ \text { mr'a } & \text { 'woman' } \\ \text { bləs } & \text { 'swallow' } \\ \text { gləs } & \text { 'sit down' }\end{array}$

b. SO

rfa 'he corrupted' nsa 'he forgot' r'ma 'he throw'

lbən 'milk'

lga 'he found' c. $\mathrm{OO}$

$\begin{array}{ll}\text { ktab } & \text { 'book' } \\ \text { kdub 'lies' } \\ \text { Jkun 'who's there?' } \\ \text { xbar' } & \text { 'news' } \\ \text { dkər } & \text { 'male' }\end{array}$

MA exhibits sequences of rising sonority (4a), but also their mirror images (4b). The forms in (4c) show clusters with obstruents, some of which have a sonority plateau. The range of word-initial sequences allowed in MA goes well beyond the set defined in (4). Any CC combination is possible, regardless of the relative sonority of the consonants. Apart from geminates and certain NC clusters (see Harrell 1962: 34, and Heath 2002: 356), all other CC clusters can be split by an epenthetic vowel when the phonotactic conditions are met. For instance, the initial cluster in glas 'he sat down' (from CA zalasa) hosts an epenthetic vowel in the corresponding plural galsu 'they sat down'. Further evidence for the absence of 
complex onsets in MA is provided in Shaw et al. (2009). The results of their study show a heterosyllabic parsing of initial clusters in words such as ktab 'book' and sbati 'belt'.

The Berber languages do not diverge from this trend, as no sonority restriction is imposed on their consonant clusters. Word-initial CC may consist of a sequence of stops or obstruent-sonorant, each with their mirror-image. Examples are given in Tashlhiyt Berber.

\begin{tabular}{clrlrl} 
a. OS & \multicolumn{3}{c}{ b. SO } & \multicolumn{3}{c}{ c. OO } \\
kru & 'rent' & rku & 'be dirty' & kti & 'remember' \\
bri & 'scratch' & rbu & 'carry on the back' & bsi & 'melt' \\
gnu & 'sew' & ngi & 'overflow' & sti & 'pick out' \\
dlu & 'cover' & ldi & 'pull' & zd'arn 'they are able'
\end{tabular}

In a recent study, Ridouane et al. (2014) showed that prevocalic clusters of the type in (5) behave as heterosyllabic, regardless of their sonority profile and their position within the word.

As to word-final position, $\mathrm{CC}$ clusters are generally simplified by means of epenthesis in all Berber varieties where no consonant syllabicity is found (e.g. Tamazight Berber $f \theta a l$ 'roll', d'lam 'accuse wrongly'), except for geminates and homorganic clusters, to which we will turn later in section 2. Needless to say that any internal $\mathrm{CC}$ which occurs in intervocalic position is syllabified as a coda+onset sequence, according to standard analyses. The reader is referred to Bensoukas \& Boudlal $(2012 \mathrm{a}, \mathrm{b})$ for a comparative study on the phonology of schwa in Tamazight and MA.

The state of affairs in Arabic and Berber, only partially documented here, leads to the view that such languages, which do not impose sequential constraints on clustering and seem to resort to an extensive use of epenthetic vowels, can be analyzed as having only open syllables at the phonological level. This proposal, first made by Guerssel (1990) on Tamazight Berber and Kaye (1990) on MA, has been extended to other Berber varieties (see Bendjaballah 1999, 2005 and Ben Si Said on Kabyle, and Lahrouchi 2001, 2003 on Tashlhiyt) and to many other languages (see Barillot 2002 and Lampitelli on Somali, Rucart 2006 on Afar, and Faust 2011 on Hebrew).

The next section will show how the vowel-zero alternations and the surface clusters provide much support for the idea that empty nuclei play a central role in the syllable structure of MA and Berber. The strict CV model (also termed CVCV) will be used as a unifying approach to these phenomena, making the role of standard syllabic constituents unnecessarily redundant. 


\section{Strict CV approach to syllable structure and vowel-zero alternations}

\subsection{CVCV model}

The CVCV approach to syllable structure (Lowenstamm 1996), which falls within the general framework of Government Phonology (Kaye et al. 1990), holds that syllable structure universally boils down to strict alternations of non-branching onsets (i.e. C positions) and non-branching nuclei (i.e. V positions), which interact laterally to derive various syllable types. The familiar closed syllables, complex onsets and nuclei, long vowels and geminates are represented as follows.

(6)

a. closed syllable b. complex onset $\quad$ c. long vowel $\quad d$. geminate

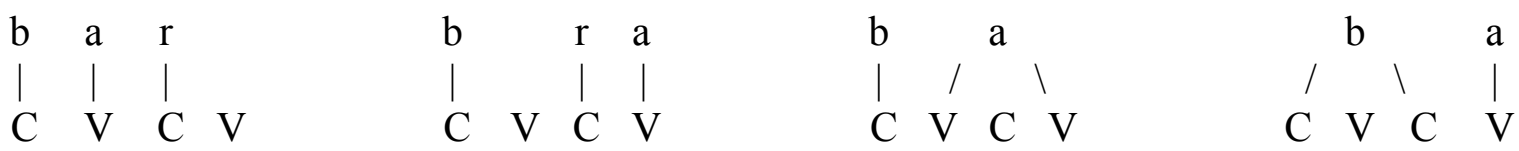

[bar]

[bra]

[ba: ]

$[\mathrm{b}: \mathrm{a}]$

As can be seen from these representations, there are no rhymes, no codas and no branching constituents. The differences in the surface syllabic structures lie in the way segments are associated to $\mathrm{C}$ and $\mathrm{V}$ positions:

a. The postvocalic consonant of the surface closed syllable in (6a) appears in the onset of the second syllable, whose nucleus is empty.

b. The complex onset in (6b) has an empty nucleus between its consonants.

c. The long vowel in (6c) has an empty $\mathrm{C}$ between its members, whereas the geminate in (6d) contains an empty V.

Any skeletal position which has no phonetic realization is said to be licensed to remain empty by virtue of the government relation it shares with the neighbouring segment. Proper Government (henceforth, PG) is one such relation, which allows a vocalic position to remain empty when followed by a vowel. This proves particularly interesting in explaining the vowel-zero alternations under close scrutiny in this chapter.

\subsection{Vowel-zero alternations}

PG is an asymmetric, local and unidirectional relation contracted by vocalic positions. (7) provides a definition of this relation as currently understood in the relevant literature (see Kaye 1990, and Scheer 2004). 


\section{(7) Proper Government}

$\alpha$ properly governs $\beta$ if

$\alpha$ and $\beta$ are adjacent at the vocalic level

$\alpha$ is located to the right of $\beta$

$\alpha$ is not itself properly governed

no governing domain intervenes between $\alpha$ and $\beta$.

The vowel-zero alternations at issue in MA and Berber are fully handled by this device, which crucially predicts that empty positions cannot be adjacent at the vocalic projection. Any sequence of two adjacent empty positions must realize one, depending on the government relation contracted with the neighbouring vowels. The position which escapes PG is generally the one that surfaces at the phonetic level. Let us illustrate this with the MA pair $k t a b / k a t b u$ :

(8)

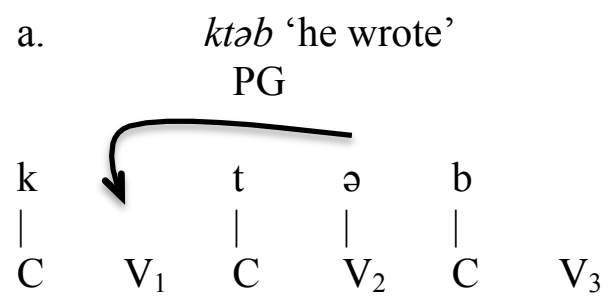

b. $\quad k a t b u$ 'they wrote'

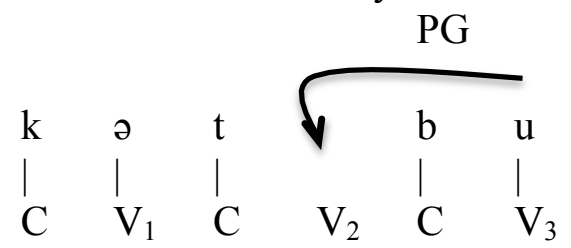

In (8a), $V_{3}$ is licensed to remain empty by virtue of being domain-final; ${ }^{5}$ therefore it is unable to properly govern the preceding nucleus. This results in the phonetic realization of $\mathrm{V}_{2}$, which then governs $\mathrm{V}_{1}$. On the other hand, the inflectional vowel $-u$ in (8b) properly governs the preceding $\mathrm{V}$ position, which in turn remains inaudible. Then $\mathrm{V}_{1}$, no more governed, surfaces as [ə]. Almost all cases of vowel/zero alternations in MA comply with this analysis, except for nouns like qalb 'heart' and $\hbar a b s$ 'jail' which exhibit an epenthetic vowel between the first two consonants. Interestingly, these nouns contrast with the verbs $q$ lab 'revert' and $\hbar b \partial s$ 'put in jail'. Following Echchadli (1986), we assume that some category-specific epenthesis is responsible for the distribution of schwa in nouns like qalb. For further details

\footnotetext{
${ }^{5}$ Within the strict $\mathrm{CV}$ model, all phonological domains end with a nucleus, which may or may not be licensed to remain empty. This parametric licensing proves necessary in distinguishing languages like English and MA where words can end in a consonant from languages like Italian where they always end in a vowel.
} 
and analysis of the distribution of epenthetic vowels in MA, the reader is referred to Kaye (1990).

The same situation obtains in the Berber varieties which resort to vowel epenthesis. (9) gives the representation of two forms of the verb $x ð m$ 'to work', which involve three empty nuclei, each of which can surface if it escapes PG.

(9) Tamazight Berber

a. $x ð ə m$ 'work!'

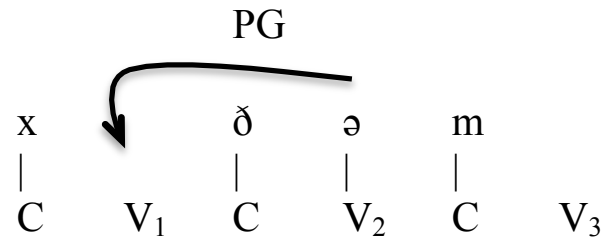

b. xəðməx 'I worked'

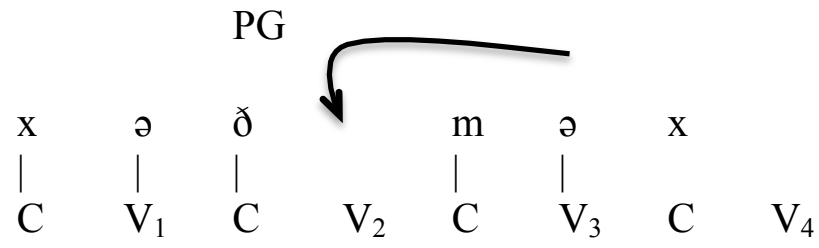

The computation of empty nuclei proceeds in much the same way it does in MA. Domain-final ones are licensed to remain empty, therefore allowing the preceding nuclei to be realized. In (9a), $\mathrm{V}_{2}$ surfaces as schwa and then governs $\mathrm{V}_{1}$, leading to the form $x \partial ə m$, which exhibits an initial CC cluster at the phonetic level. ${ }^{6}$ Interestingly, this cluster gets its empty nucleus interpreted in $(9 \mathrm{~b})$, while $\mathrm{V}_{2}$ properly governed by $\mathrm{V}_{3}$ remains silent. In fact, the difference between the two forms in (9) lies in the suffixation of the $1^{\text {st }}$ person marker, which disrupts the distribution of empty vocalic positions. The unidirectional application of PG predicts that any penultimate empty nucleus must surface, except when it is followed by another vowel or when it is a member of a geminate or homorganic cluster. In Tamazight, for instance, neither the final geminate in ggall 'swear' nor the final cluster in Oaqbilt 'tribe' undergoes vowel epenthesis. Their vocalic position remains silent for it is located within a branching structure which prevents it from surfacing. The representations in (10) show how homorganic clusters and geminates, whose integrity is well-documented in the literature (Schein \& Steriade 1986, and Hayes 1986), display branching structures within the strict CV approach.

\footnotetext{
${ }^{6}$ әxðəm is another pronounciation of the verb (cf. Saïb 1976, Abdelmasih 1971). Forms of this type may exhibit schwa at the beginning, perhaps in order to avoid the initial cluster.
} 
a.

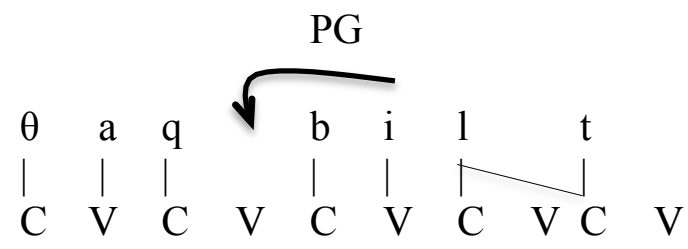

b.

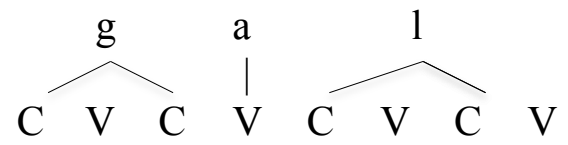

The branching structure of final /lt/ in (10a) not only blocks vowel epenthesis but also prevents final / $\mathrm{t} /$ from being spirantized, as generally expected for stops in Tamazight (e.g. initial /t/ > $[\theta]$ in (10a), /tajdit/ > [ ajdi $\theta]$ 'she-dog'). According to Ulfsbjorninn \& Lahrouchi (2016: 120), this kind of cluster branches by sharing a closure feature (also termed |?| element, cf. Harris 1994, and Backley 2011). The branching structure of the geminates in (10b) allows them resist epenthesis in a similar fashion.

The facts just discussed clearly show how the strict CV approach captures the distribution of epenthetic vowels and surface clustering under the same operation of Proper Government. There is no need for any specific constraint on syllable margins: the ban of complex coda and onset naturally obtains as the result of the phonological computation of empty vocalic positions. The ones which escape PG are filled with the language-specific default vowel, namely schwa in Berber and MA.

In Tashlhiyt Berber, where no epenthetic schwa is found, syllabic consonants arise. The next section turns to this issue. It is argued that any vocalic position lacking PG systematically hosts one syllabic consonant (see Hammane 2010 on Tashlhiyt; Blaho 2004 and Scheer 2008 on Slavic, and Beltzung \& Patin 2007 on Coptic).

\section{Syllabic consonants in Tashlhiyt Berber}

\subsection{Words without vowels}

One major feature of Tashlhiyt Berber is its extensive use of consonant clusters, which may result in utterances without any vocalic segment (e.g. tsslkmttnt 'you made them (fem.) arrive'). Based on this characteristic, Dell \& Elmedlaoui $(1985,1988,2002)$ argued that in Tashlhiyt any segment, even a voiceless obstruent, can be syllabic (see also Boukous 1987, and Ridouane 2008). The so-called "transitional vocoids", which appear in certain consonant clusters (e.g. nkar 'wake up, stand up', lkam 'arrive'), have no syllabic status according to 
Dell \& Elmedlaoui (2002), while Coleman (1996, 2001) argues that they are epenthetic, filling syllabic nuclei that would otherwise remain empty.

In fact, these schwa-like vowels are found in very specific contexts, that is in the immediate vicinity of sonorants and voiced obstruents. In utterances with voiceless obstruents, no vowels are found (e.g. kktt 'go through it (FM)' , fftt 'eat it (FM)', tsskfftstt 'you fade it (FM)), contrary to the varieties which resort to scwha epenthesis.

I here adopt the idea that any segment, even a voiceless obstruent, may act as a syllable nucleus. However, I claim that the competition for the nucleus position is not always driven by the relarive sonority of segments. Rather, it is the lateral interaction between vocalic positions that determines which consonant can be syllabic.

\subsection{Syllabic consonants in strict $\mathrm{CV}$}

In order to bring out the specificity of Tashlhiyt syllable structure, let us consider the verbs хðəm 'work!' and хәðmәx 'I worked' discussed in Tamazight Berber under (9). In Tashlhiyt, no epenthetic vowel appears in the phonetic form of these verbs. They surface as $x d m$ and $x d m x$ (where $C_{1}$ stands for syllabic consonant).

The strict $\mathrm{CV}$ approach along with its government device allows syllabic consonants to attach to vocalic positions. Any position which lacks PG is filled by the consonant immediately to its left. In $x d m$, the consonant $/ \mathrm{m} /$ fills the $\mathrm{V}$ position to its left and then governs the empty $\mathrm{V}$ between $/ \mathrm{x} /$ and /d/ (11a), whereas in $x d m x$ it is the consonants $/ \mathrm{x} / \mathrm{and}$ /d/ that branch into the ungoverned $\mathrm{V}$ positions (11b).

(11) Tashlhiyt Berber

a. $\quad x d m$ 'work - imperative $2 \mathrm{sg}$ '

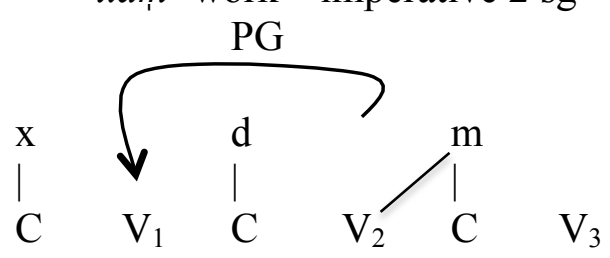

b. $\quad x d m x$ 'I worked'

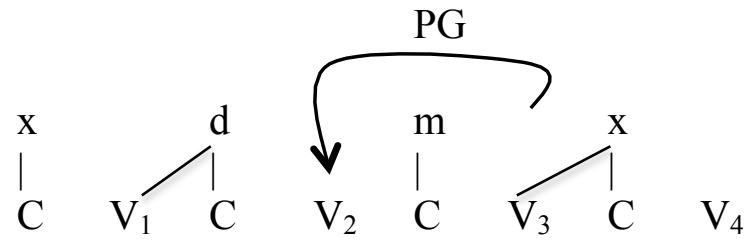


The left-branching representation of syllabic consonants is supported by the distribution of epenthetic vowels in the Berber varieties where only vocalic elements appear in the nucleus position, including the aforementioned Tamazight variety. Indeed, the careful reader will have noticed that the syllabic consonants in Tashlhiyt forms are exactly the ones preceded by an epenthetic schwa in Tamazight. Further evidence is found in languages such as English and German, where many instances of $ə \mathrm{C}$ are in free variation with syllabic $\mathrm{C}$ : In German, for instance, ha:bən 'to have' and ge:bən 'to give' alternate with ha:bm and ge:bm, respectively (cf. Clark \& Yallop 1995: 68). The reader is referred to Scheer (2004) for similar facts in Czech and Polish.

Further evidence for the proposal put forth in this section is drawn from the length alternation of the causative morpheme. The next section argues that such an alternation derives from the distribution of nuclei, including those hosting syllabic consonants.

\subsection{Causative formation in Tashlhiyt Berber}

In Tashlhiyt, like in many other Berber varieties, the causative verb is built by means of a mono-consonantal prefix attached to a stem. This prefix is realized as single or geminated depending on the properties of the stem. The examples in (12) illustrate the phenomenon.

(12) Verb

$\begin{array}{lll}\text { a. mun } & \text { 'gather' } \\ & \text { br'br } & \text { 'boil' } \\ \text { gawr } & \text { 'sit' } \\ \text { bukd' } & \text { 'be blind' } \\ \text { b. } & \text { anf } & \text { 'move away' } \\ \text { imlul } & \text { 'be white' } \\ \text { knu } & \text { 'lean' } \\ \text { r'mi } & \text { 'be tired' } \\ \text { xdm } & \text { 'work' } \\ \text { lkm } & \text { 'arrive' }\end{array}$

\section{Causative}

$\begin{array}{ll}\text { smun } & \text { 'pick up' } \\ \text { sbr'br } & \text { 'make boiled' } \\ \text { sgawr } & \text { 'make sit' } \\ \text { sbukd' } & \text { 'blind } \\ \text { ssanf } & \text { 'move' } \\ \text { ssimlul } & \text { 'whiten' } \\ \text { ssknu } & \text { 'tilt' } \\ \text { ssr'mi } & \text { 'tire' } \\ \text { ssxdm } & \text { 'make someone work' } \\ \text { sslkm } & \text { 'make arrive' }\end{array}$

The data suggest that verbs beginning with a CV sequence select the simplex variant of the prefix, while those that begin with two consonants take the geminated variant. The verbs which consist entirely of consonants do diverge from this trend. As we will show shortly, the vocalic positions hosting syllabic consonants play the same role as plain vowels.

According to my analysis, the causative prefix is underlyingly simplex (see also Guerssel 1992, Jebbour 1999, Lahrouchi 2001, 2003, and Hammane 2010). It geminates by 
spreading into the following empty onset, which only verbs with an initial vowel or syllabic consonant provide. Otherwise, the prefix remains simplex. The representations in (13) show how the distribution of vowels determines the shape variation of the causative prefix.

a. smun 'pick up'

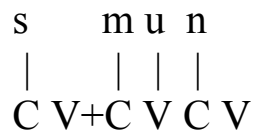

b. ssimlul 'whiten'

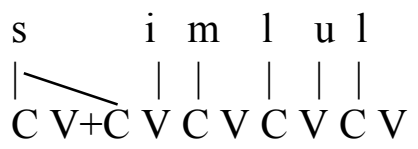

In (13b), /s/ geminates by spreading into the following empty onset. In contrast, in (13a), the prefix remains simplex since the base verb begins with a consonant. The same situation obtains in the verbs which have syllabic consonants: the prefix geminates when it is is followed by an onsetless syllable, whose nucleus hosts a syllabic consonant; otherwise it remains simplex. The examples represented in (14) illustrate both situations.

a. $s s_{1} x d m$ 'employ'

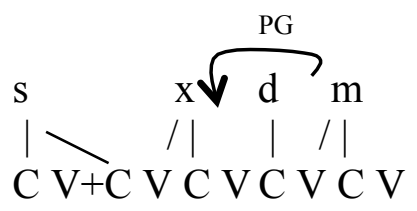

b. sbrbr 'boil'

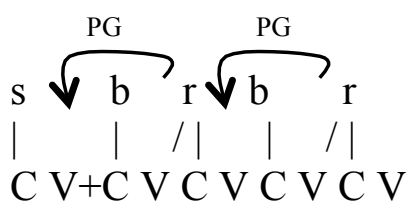

As explained in section 3.2, PG regulates the distribution of syllabic consonants: any ungoverned $\mathrm{V}$ position can host a syllabic consonant, which then governs the preceding $\mathrm{V}$ position, just as plain vowels do in the Berber varieties which have no syllabic consonants. As a matter of comparison, the form in (14a) surfaces in Tamazight Berber as ssəxðəm, with a geminated causative prefix like in Tashlhiyt, plus schwa epenthesis in the stem-initial position and between the last two consonants. The stem-initial syllable, whose onset is empty, allows the causative prefix to geminate (see 15a). Conversely, a verb bargan takes the simplex variant of the prefix (15b).

(15) Tamazight Berber
a. ssaxðəm 'employ'
b. sbargan 'put on face (scarf)'
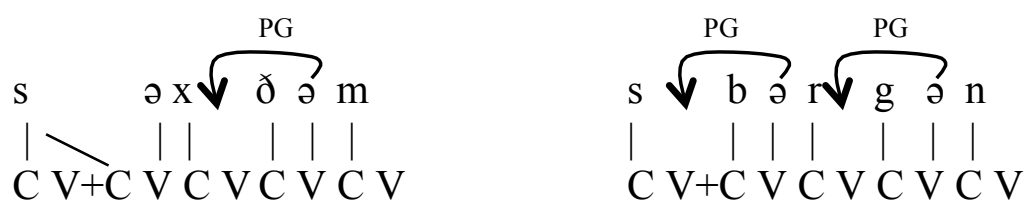

A rapid comparison between these representations and the ones in (14) clearly shows that the shape of the stem-initial syllable, be it headed by an schwa or a syllabic consonant, 
determines the length variation of the causative prefix. This prefix geminates whenever it is followed by an empty onset position.

The strict CV approach captures clearly the parallel between the distribution of epenthetic vowels and syllabic consonants. Both strategies (epenthesis and consonant syllabicity) lead to the same result: MA and Berber can be analyzed as having only open syllables at the phonological level.

\section{Conclusion}

Based on previous work, I have argued that the vowel/zero alternations found in Tamazight Berber and Moroccan Arabic can be explained in terms of lateral relations between empty nuclei, rather than hierarchical structure. Within the strict CV approach, I have shown that consonant clusters result from the computation of empty nuclei, some of which remain silent when they are properly governed by the following vowel. There is no need for any specific constraint on complex constituents, be they codas or onsets.

In Tashlhiyt Berber, where no epenthetic schwa is found, syllabic consonants arise. The distribution of these consonants proceeds in much the same way as the epenthetic vowels in Tamazight Berber and Moroccan Arabic: any empty position which escapes proper government systematically hosts a syllabic consonant. One piece of evidence in favour of this analysis is drawn from the causative formation. I have shown that the distribution of syllabic consonants determines the shape of the causative prefix in the same way plain vowels do: the prefix geminates into the following empty onset, be it adjacent to a vowel or syllabic consonant.

\section{References}

Abdelmasih, Ernest T. 1971. A reference grammar of Tamazight. Ann Arbor: University of Michigan.

Ali, N. Azra, Lahrouchi, Mohamed \& Ingleby, Michael. 2008. Vowel Epenthesis, Acoustics and Phonology Patterns in Moroccan Arabic. In Proceedings of Interspeech 2008, 1178-1181. Brisbane, Australia.

Awbery, Gwenllian. 1984. Phonotactic constraints in Welsh. In Welsh phonology, Martin Ball \& Glyn E. Jones (eds.), 65-104. Cardiff: University of Wales Press.

Backley, Philip. Element theory, an introduction. Edinburgh: Edinburgh University Press.

Bader, Yousef. 1985. Schwa in Berber: A non linear analysis. Lingua 67: 225-249. 
Barillot, Xavier. 2002. Morphophonologie gabaritique et information consonantique latente en somali et dans les langues Est-couchitiques. $\mathrm{PhD}$ dissertation, University of Paris 7. Bauer, Laurie. 2015. English phonotactics. English Language and Linguistics 19/3: 437-475. Beltzung, Jean-Marc \& Cédric Patin. 2007. Quand le schwa n'est là...Schwa est consonnes syllabiques en copte. In Proceedings of JEL'2007, Olivier Crouzet \& Jean-Pierre Angoujard (eds), 15-20. Nantes: University of Nantes.

Bendjaballah, Sabrina. 1999. Trois figures de la structure interne des gabarits: activité morphologique du niveau squelettal des représentations phonologiques en berbère, somali et bedja. $\mathrm{PhD}$ dissertation, Université Paris 7.

Bendjaballah, Sabrina. 2001. The « Negative Preterit» in Kabyle Berber. Folia Linguistica XXXIV/3-4: 185-220.

Bendjaballah, Sabrina. 2005. Longueur phonologique des voyelles en kabyle. Etudes et documents berbères 22: 47-69.

Benhallam, Abderrafi. 1980. Syllable structure and rule types in Arabic. $\mathrm{PhD}$ dissertation, University of Florida.

Benhallam, Abderrafi. 1989/1990. Moroccan Arabic syllable structure. Langues et Littératures 8: 177-191.

Ben Si Said, Samir. 2014. De la nature de la variation diatopique en kabyle: étude de la formation des singulier et pluriel nominaux. $\mathrm{PhD}$ dissertation, University of Nice.

Bensoukas, Karim \& Abdelaziz Boudlal. 2012a. The prosody of Moroccan Amazigh and Moroccan Arabic: Similarities in the phonology of schwa. In Prosody Matters: Essays in honor of Lisa Selkirk, Toni Borowsky, Shigeto Kawahara, Takahito Shinya \& Mariko Sugahara (eds.), 3-42. London: Equinox.

Bensoukas, Karim \& Abdelaziz Boudlal. 2012b. An Amazigh substratum in Moroccan Arabic: The prosody of schwa. Langues et Littératures 22: 179-221.

Blaho, Sylvia. 2004. Interactions of sonorant and obstruent voicing. Master's thesis, Pázmány Péter Catholic University.

Booij, Geert. 1995. The phonology of Dutch. Oxford: Clarendon Press.

Boudlal, Abdelaziz. 2001. Constraint Interaction in the Phonology and Morphology of Casablanca Moroccan Arabic. Doctorat d'Etat thesis, Mohammed V University, Rabat.

Boudlal, Abdelaziz. 2006/2007. Sonority-driven schwa epenthesis in Moroccan Arabic. Languages and Linguistics 18/19: 59-81.

Boukous, Ahmed. 1987. Phonotactique et domaines prosodiques en berbère. $\mathrm{PhD}$ 
dissertation, University Paris 7.

Chaker, Salem. 1992. Une décennie d'études berbères (1980-1990). Bibliographie critique: langue, littérature, identité. Algiers: Bouchène.

Charette, Monik. 1990. License to Govern. Phonology 7: 233-253.

Clark, John \& Colin Yallop. 1995. An introduction to phonetics and phonology. Oxford: Blackwell.

Coleman, John. 1996. Declarative syllabification in Tashlhiyt Berber. In Current Trends in Phonology: Models and Methods. Vol. 1, J. Durand \& B. Laks (eds), 177-218. Salford: European Stufies Research Institute, University of Salford.

Coleman, John. 2001. The phonetics and phonology of Tashlhiyt Berber syllabic consonants. Transactions of the Philological Society 99: 29-64.

Dell, François. 1973. Les Règles et les Sons. Introduction à la phonologie générative, $2^{\mathrm{e}}$ édition, Paris, 1985: Hermann.

Dell, François \& Mohamed Elmedlaoui. 1985. Syllabic Consonants and Syllabification in Imdlawn Tashlhiyt Berber. Journal of African Languages and Linguistics 7: 105-130.

Dell, François \& Mohamed Elmedlaoui. 1988. Syllabic Consonants in Berber: Some New Evidence. Journal of African Languages and Linguistics 10: 1-17.

Dell, François \& Mohamed Elmedlaoui. 2002. Syllables in Tashlhiyt Berber and in Moroccan Arabic. Dordrecht: Kluwer.

Echchadli, Malika. 1986. Les processus morphologiques et phonologiques des noms en arabe marocain. MA thesis, Montréal, UQAM.

Elramli, Youssef Mokhtar. 2012. Assimilation in the phonology or a Lybian Arabic dialect: A constraint-based approach. $\mathrm{PhD}$ dissertation, Newcastle Univresity.

Faust, Noam. 2011. Forme et fonction dans la morphologie nominale de l'hébreu moderne: études en morpho-syntaxe. $\mathrm{PhD}$ dissertation, Univresity of Paris 7.

Frankiewicz, Justina. 2001. A syllabic analysis of vowel epenthesis in the suffix $-e d$ in English. Poznan Studies in Contemporary Linguistics 37: 53-69.

Guerssel, Mohamed. 1990. On the syllabification pattern of Berber. Montreal: ms, UQAM.

Guerssel, Mohamed. 1992. The phonology of Berber derivational morphology by affixation. Linguistic Analysis 22/1-2: 03-60.

Gussmann, Edmund. 1980. Introduction to phonological analysis. Warszawa: Panstwowe Wydawnictwo Naukowe.

Haddad, Ghassan. 1984. Epenthesis and sonority in Lebanese Arabic. Studies in the Linguistic 
Sciences 14: 57-88.

Hall, Nancy. Vowel epenthesis. In The Blackwell companion to phonology. 5 vols, Marc van Oostendorp, Colin J. Ewen, Elizabeth Hume \& Keren Rice (eds.), 1576-1596. Malden, MA \& Oxford: Wiley-Blackwell.

Hall, Nancy. 2013. Acoustic differences between lexical and epenthetic vowels in Lebanese Arabic. Journal of Phonetics 41/2: 133-143.

Hammane, Khadija. 2010. La syllabe en berbère tachlhit: que peut apporter la théorie $C V C V$ ? Ph.D dissertation, University Paris 8.

Harrel, Richard. 1962. A short reference grammar of Moroccan Arabic. Washington, DC: Georgetown University Press.

Harris, John 1994. English sound structure. Oxford: Blackwell.

Hayes, Bruce . 1986. Inalterability in CV phonology. Language 62: 321-351.

Heath, Jeffrey. 2002. Jewish and Muslim dialects of Moroccan Arabic. London: Curzon.

Idrissi, Ali. 2000a. On Berber plurals. In Research in Afroasiatic Grammar, Jacqueline Lecarme, Jean Lowenstamm \& Ur Shlonsky (eds.), 101-124. Amsterdam: John Benjamins.

Idrissi, Ali. 2000b. Towards a root-and-template approach to shape-invariant morphology. $\mathrm{PhD}$ dissertation, UQAM.

Itô, Junko. 1989. A prosodic theory of epenthesis. Natural Language and Linguistic Theory 7: 217-259.

Jebbour, Abdelkrim. 1993. A note on blind roots in Berber. Linguistica Communicatio III: 211-24.

Jebbour, Abdelkrim. 1999. Syllable weight and syllable nuclei in Tachelhit Berber of Tiznit. Cahiers de Grammaire 24: 95-116.

Kabbaj. Ouadia. 1990. La structure syllabique de l'arabe marocain. MA thesis, UQAM.

Kaye, Jonathan.1990. Government in Phonology: the case of Moroccan Arabic. The Linguistic Review 6: 131-159.

Kaye, Jonathan, Malika Echchadli \& Souad El Ayachi. 1986. Les formes verbales de l'arabe marocain. Revue Québecoise de Linguistique 16/1: 61-98.

Kaye, Jonathan, Jean Lowenstamm \& Jean-Roger Vergnaud. 1990. Constituent Structure and Government in Phonology. Phonology 7/2: 193-231.

Kenstowicz, Michael. 1986. Notes on syllable structure in three Arabic dialects. Revue Québecoise de Linguistique 16/1: 101-127. 
Kossmann, Maarten. 1995. La spirantisation dans les parlers Zénètes. In Langues du Maroc: aspects linguistiques dans un contexte minoritaire, Petra Bos (ed.),11-19. Tilburg: Tilburg University Press.

Lahrouchi, Mohamed. 2001. Aspects morpho-phonologiques de la dérivation verbale en berbère tachelhit. $\mathrm{PhD}$ dissertation, University of Paris 7.

Lahrouchi, Mohamed. 2003. Manifestations gabaritiques dans la dérivation verbale en berbère tachelhit. Recherches Linguistiques de Vincennes 32: 61-82.

Lahrouchi, Mohamed \& Philippe Ségéral. 2010. Peripheral vowels in Tashlhiyt Berber are phonologically long: Evidence from Tagnawt. Brill's Annual of Afroasiatic Languages and Linguistics 2: 202-212.

Lampitelli, Nicola. 2011. Forme phonologique, exposants morphologiques et structures nominales : études comparées de l'italien, du bosnéen et du somali. $\mathrm{PhD}$ dissertation, University of Paris 7.

Lowenstamm, Jean. 1991. Vocalic length and centralization in two branches of Semitic. In Semitic Studies in Honor of Wolf Leslau on the Occasion of his 85th Birthday, vol. 2, Alan S. Kaye (ed.), 949-65. Wiesbaden: Harrasowitz

Lowenstamm, Jean. 1996. CV as the Only Syllable Type. In Current Trends in Phonology Models and Methods, J acques Durand \& Bernard Laks (eds.), 419-442. University of Salford, European Studies Research Institute.

Nikiema, Emmanuel. 1989. Gouvernement Propre et licenciement en phonologie : le cas du Tangale. Langues Orientales Anciennes, Philologie et Linguistique 2: 225-251.

Oostendorp, van, Marc. 1995. Vowel quality and phonological projection. $\mathrm{PhD}$ dissertation, Tilburg University.

Ridouane, Rachid. 2008. Syllables without vowels: Phonetic and phonological evidence from Tashlhiyt Berber. Phonology 25: 321-359.

Ridouane, Rachid, Anne Hermes \& Pierre André Hallé. 2014. Tashlhiyt's ban of complex syllable onsets: phonetic and perceptual evidence. Language Typology and Universals 67/1: 7-20.

Rucart, Pierre. 2006. Morphologie gabaritique et interface morphosyntaxique. $\mathrm{PhD}$ dissertation, University of Paris 7.

Saïb, Jilali. 1976. A phonological study ofTamazight Berber: dialect of Ayt Ndhir. Ph.D. dissertation, University of California, Los Angeles.

Scheer, Tobias. 2004. A Lateral Theory of Phonology: What is CVCV, and why should it be?, Studies in Generative Grammar 68.1. Mouton de Gruyter: Berlin. 
Scheer, Tobias. 2008. Syllabic and Trapped Consonants in (Western) Slavic: the Same but yet Different. In Formal Description of Slavic Languages: The Fifth Conference, Leipzig 2003, Gerhild Zybatow, Luka Szucsich, Uwe Junghanns \& Roland Meyer (eds.), 149167. Frankfurt am Main: Lang.

Schein, Barry \& Donca Steriade. 1986. On geminates. Linguistic Inquiry 17: 691-744.

Shaw, Jason, Adamantios Gafos, Philip Hoole \& Chakir Zeroual. 2009. Temporal evidence for syllabic structure in Moroccan Arabic: Data and model. Phonology 26/1: 187-215.

Taïfi, Miloud. 1991. Dictionnaire Français-Tamazight. Paris: L'Harmattan.

Ulfsbjorninn, Shanti \& Mohamed Lahrouchi. 2016. The typology of the distribution of Edge: The propensity for bipositionality. Papers in Historical Phonology 1: 109-129. http://journals.ed.ac.uk/pihph/index

Wise, Hilary. 1983. Some functionally motivated rules in Tunisian phonology. Journal of Linguistics 19/1: 165-181. 